\title{
Semiarid grassland responses to short-term variation in water availability
}

\author{
Martin Köchy ${ }^{1,2}$ and Scott D. Wilson ${ }^{1, *}$ \\ ${ }^{1}$ Department of Biology, University of Regina, Regina, SK S4S 0A2, Canada; ${ }^{2}$ Section for Vegetation Ecology \\ and Nature Conservation, Institute for Biochemistry and Biology, Universität Potsdam, Postfach 6015 53, \\ 14415 Potsdam, Germany; *Author for correspondence (phone: 306-585-4287; fax: 306-585-4894; e-mail: \\ scott.wilson@uregina.ca)
}

Received 30 December 2002; accepted in revised form 23 August 2003

Key words: Biomass, Drought, Light, Rainfall, Soil moisture, Species composition

\begin{abstract}
Standing crop and species composition in semiarid grassland are linked to long-term patterns of water availability, but grasslands are characterized by large single-season variability in rainfall. We tested whether a single season of altered water availability influenced the proportions of grasses and shrubs in a semiarid grassland near the northern edge of the North American Great Plains. We studied stands of the clonal shrub snowberry (Symphoricarpos occidentalis) and adjacent grassland dominated by the native grasses Stipa spartea and Bouteloua gracilis. Rain was excluded and water supplied in amounts corresponding to years of low, medium, and high rainfall, producing a 2 - 4-fold range in monthly precipitation among water supply treatments. There were ten replicate plots of each water treatment in both snowberry stands and grassland. Grass standing crop increased significantly with water availability in grassland but not inside snowberry stands. Total standing crop and shrub stem density increased significantly with water supply, averaged across both communities. In contrast, water had no effect on shrub standing crop or light penetration. In summary, our finding that water has significant effects on a subset of components of grassland vegetation is consistent with long-term, correlational studies, but we also found that a single season of altered water supply had no effect on other important aspects of the ecosystem.
\end{abstract}

\section{Introduction}

The standing crop and species composition of grasslands are controlled by water availability on the regional or global scale, and on the temporal scale of decades (Sala et al. 1988; Lauenroth and Sala 1992; Epstein et al. 1997). Over the long term, increased water availability increases the proportion of grasses with $\mathrm{C}_{3}$ photosynthesis (Barnes and Harrison 1982; Epstein et al. 1997), grass root production (Hook and Lauenroth 1994), and the establishment of woody species (Harrington 1991). Because woody vegetation in grasslands is associated with moist soils (Scholes and Archer 1997; Li and Wilson 1998), the balance between woody and grassy vegetation may be influenced by water availability. For example, the inten- sity of competition exerted by herbaceous neighbors on oak seedlings in a Minnesota savanna was decreased significantly by increasing water availability (Davis et al. 1998). Increasing atmospheric $\mathrm{CO}_{2}$ concentrations may also favor woody invasions by increasing the relative water use efficiency of $\mathrm{C}_{3}$ shrubs (Polley et al. 1994). Woody plants may be more sensitive to water variability than are grasses because they tend to have thicker roots, lower root: shoot ratios, and $\mathrm{C}_{3}$ photosynthetic pathways, making them less efficient at acquiring and using water.

Grasslands, however, are characterized by great among-year variation in rainfall (Knapp and Smith 2001). In the short-term, such as a single year, water typically has no effect on the germination of native grasses (Fair et al. 1999), or the growth of transplants 
of grasses (Peltzer and Wilson 2001; Bakker and Wilson 2001) or shrubs (Carpenter and West 1987). Experiments in the Great Plains of North America found intense competition between grasses and shrubs for light and nitrogen, but not for water (Köchy and Wilson 2000). Similarly, long-term studies showed that the recruitment of a desert tree was determined more by biotic factors than by water (Bowers and Turner 2002). These results suggest that the dominance of woody plants on relatively moist soils may be related to factors other than soil moisture, such as nutrients or competition. The contrast between long-term studies, which find a relationship between water and vegetation responses, and many short-term studies, which do not, suggests that water effects accumulate over time and may not result from single-season variation in water availability. Thus, our goal was to test whether a single season of altered water availability influenced grassland standing crop, with special attention paid to the relative abundance of grasses and woody plants.

\section{Methods}

We worked in mixed-grass prairie in The Gap Community Pasture $\left(104^{\circ} 38^{\prime} \mathrm{W}, 49^{\circ} 18^{\prime} \mathrm{N}\right), 120 \mathrm{~km} \mathrm{~S}$ of Regina, Canada. The climate is continental, with average temperatures in July and January of $19{ }^{\circ} \mathrm{C}$ and $-18{ }^{\circ} \mathrm{C}$ respectively. Annual precipitation is 384 $\mathrm{mm}$, which mostly falls in May and June (Environment Canada, unpublished data). The area was not grazed during our study and had been only lightly grazed within memory. The prairie includes scattered clonal stands of the shrub snowberry (Symphoricarpos occidentalis) which have a sparse undergrowth of grasses and sedges. The grassland outside snowberry stands is dominated by Stipa viridula Trin., S. spartea Trin., S. comata Trin. and Rupr., Bouteloua gracilis (HBK.) Lag., Koeleria gracilis Pers., Agropyron spp., and Poa spp. (all $\mathrm{C}_{3}$ except Bouteloua). Nomenclature follows Looman and Best (1987).

We worked at ten sites scattered across an area of about $0.25 \mathrm{~km}^{2}$. Within each site we established six plots (40 cm diameter, separated by $\geq 1 \mathrm{~m}$ ) in May 1995 by trenching $15 \mathrm{~cm}$ deep and lining the perimeter with plastic lawn edging $(10 \mathrm{~cm}$ deep $)$. This depth excludes most grass and shrub roots (Jackson et al. 1997). Three plots were established within dense stands of snowberry, and three other plots were set up $\leq 5 \mathrm{~m}$ away in grassland. All plots in snow-

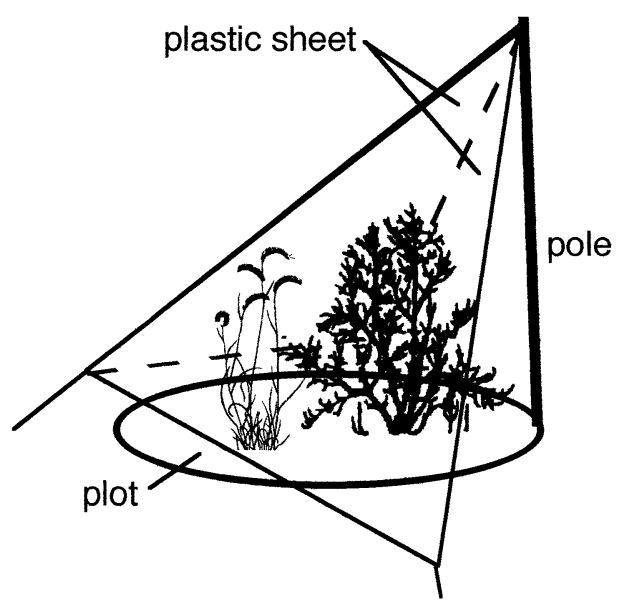

Figure 1. Tent for excluding rain from plots. The tent was constructed of a square sheet of clear plastic $(60 \times 60 \mathrm{~cm})$ fastened to a line running from the top of a pole ( $1 \mathrm{~m}$ tall), on the SW side of the plot, to the ground on the NE side. The two corners of the sheet were staked to shelter the plot from the SW and NW, the dominant wind directions during summer rains.

Table 1. Monthly water ( $\mathrm{mm})$ supplied to plots in the three water treatments.

\begin{tabular}{lllc}
\hline & Low & Medium & High \\
\hline June & 25 & 72 & 117 \\
July & 35 & 61 & 114 \\
August & 22 & 42 & 53 \\
September & 34 & 36 & 61 \\
\hline
\end{tabular}

berry stands contained some grass and all grassland plots contained some snowberry stems. One plot in each community at each site was assigned to one of three levels of water availability: low, medium or high.

We manipulated water availability by excluding rain from all plots from June 22 to September 9, 1995 using plastic tents (Figure 1). Penetration of photosynthetically active radiation through the plastic was 93\%. The two sides of the tents faced SE and NW, the dominant wind directions on rainy days (Environment Canada unpublished data). Tents were open on the north side to allow air circulation. Plots were watered by hand every 10 days. The three levels of water availability (Table 1) reflected monthly average precipitation at Regina, the nearest station with longterm records (Environment Canada unpublished data), during 1958 - 1994. Low and high water availability reflected the five driest and wettest years, 
and medium water availability reflected the average of all years.

We measured the standing crop of grasses and shrubs in each plot in September 1995. Grass standing crop $\left(\mathrm{SC}_{\mathrm{g}}\right)$ was measured using a point-frequency counting frame. We noted the number of times that pins ( $2.5 \mathrm{~mm}$ diameter) touched grass tissue produced that year. Pins were in a $6 \times 20$ grid, separated by 6 $\mathrm{cm}$ in one direction and by $2 \mathrm{~cm}$ in the other. Only pins that fell within plots were used. These numbers were converted to mass using a regression equation $\left(\mathrm{SC}_{\mathrm{g}}(\mathrm{g})=(2.089 \text { touches/pin }+0.6976)^{2}, r^{2}=0.61\right)$ developed from 18 quadrats $(30 \times 30 \mathrm{~cm})$ in grassland and 20 in snowberry. Grasses used to develop the regression equation were cut $1 \mathrm{~cm}$ above the ground, dried to constant mass at $105^{\circ} \mathrm{C}$, and weighed. Other herbaceous species were included with grass mass. Shrub standing crop $\left(\mathrm{SC}_{\mathrm{s}}\right)$ was determined by measuring the diameter $( \pm 0.01 \mathrm{~mm})$ of each stem $4 \mathrm{~cm}$ above the ground and applying a regression equation $\left(\mathrm{SC}_{\mathrm{s}}(\mathrm{g})=0.3174 \mathrm{~d}^{2}(\mathrm{~mm})-0.7097 \mathrm{~d}+0.4458, r^{2}\right.$ $=0.98$ ) developed using 20 stems harvested outside the plots.

Light penetration was measured in each plot at 1 $\mathrm{cm}$ above the ground within $2 \mathrm{~h}$ of solar noon on a clear day (19 August) as percentage of photosynthetically active radiation above the canopy, using a 40-cm integrating strip (Sunfleck Ceptometer, Decagon Devices, Pullman, Washington).

Grass, shrub, and total standing crop, shrub stem density, and light penetration were examined with analyses of variance (ANOVA) for block-factorial designs with site as the random, blocking factor, and community (snowberry or grassland) and water availability as fixed factors. To increase homoscedasticity and normality, data were ln-transformed. ANOVAs were calculated with JMP (version 3.0.2, SAS Institute, Cary, North Carolina, USA).

\section{Results}

Grass standing crop increased significantly with water availability in grassland, but not in snowberry stands (Figure 2), resulting in a significant interaction between water and community $\left(F_{2,18}=3.8, P=\right.$ 0.04). Pairwise contrasts showed that grass standing crop in grassland was significantly higher in plots with high water availability than those with low water availability, but that standing crop in plots with medium water availability did not differ significantly from those in the low or high levels. There was no main effect of water availability on grass standing crop. Grass standing crop was significantly higher in grassland than in snowberry (Figure $2, F_{1,9}=7.27, P$ $=0.03$ ).

Shrub standing crop did not vary significantly with water supply or any interaction involving water, but was significantly higher in snowberry stands than in grassland (Figure 2, $F_{1,9}=50.8, P<0.0001$ ).

Shrub stem density increased significantly with water availability (Figure 2, $F_{2,9}=5.43, P<0.05$ ), but not with the interaction between water and community $\left(F_{2,18}=1.09\right)$, suggesting that the response of density to water supply did not differ between communities. Stem density was significantly higher in plots receiving average and high rates of water than in those receiving low rates, averaged across both communities (Figure 2). Shrub stem density was significantly higher in snowberry stands than in grassland (Figure 2, $F_{1,9}=53.68, P<0.0001$ ).

Total standing crop increased significantly with water availability (Figure $3, F_{2,18}=3.56, P=0.01$ ). Pairwise comparisons across both communities showed that total standing crop was significantly lower in plots with low water availability than in those with medium or high water availability, but that standing crop did not differ significantly between medium and high water availability. The lack of a significant interaction between community and water availability suggests that total standing crop responded to water supply the same way in snowberry and in grassland. Total standing crop was significantly higher in snowberry stands than in grassland $\left(F_{1,9}=\right.$ 43.6, $P<0.0001)$.

Light penetration also did not vary significantly with water availability or with any interaction involving water, but was significantly higher in grasslands $(51 \%)$ than in snowberry stands $\left(33 \%, F_{1,9}=45.7, P\right.$ $<0.0001)$.

\section{Discussion}

Short-term variation in water availability can influence grassland standing crop: both grass and total standing crop increased significantly with increasing water supply, as did shrub stem density (Figure 2, Figure 3 ). The magnitude of the response, however, was surprisingly modest relative to the $2-4$ fold variation among water supply treatments (Table 1), 

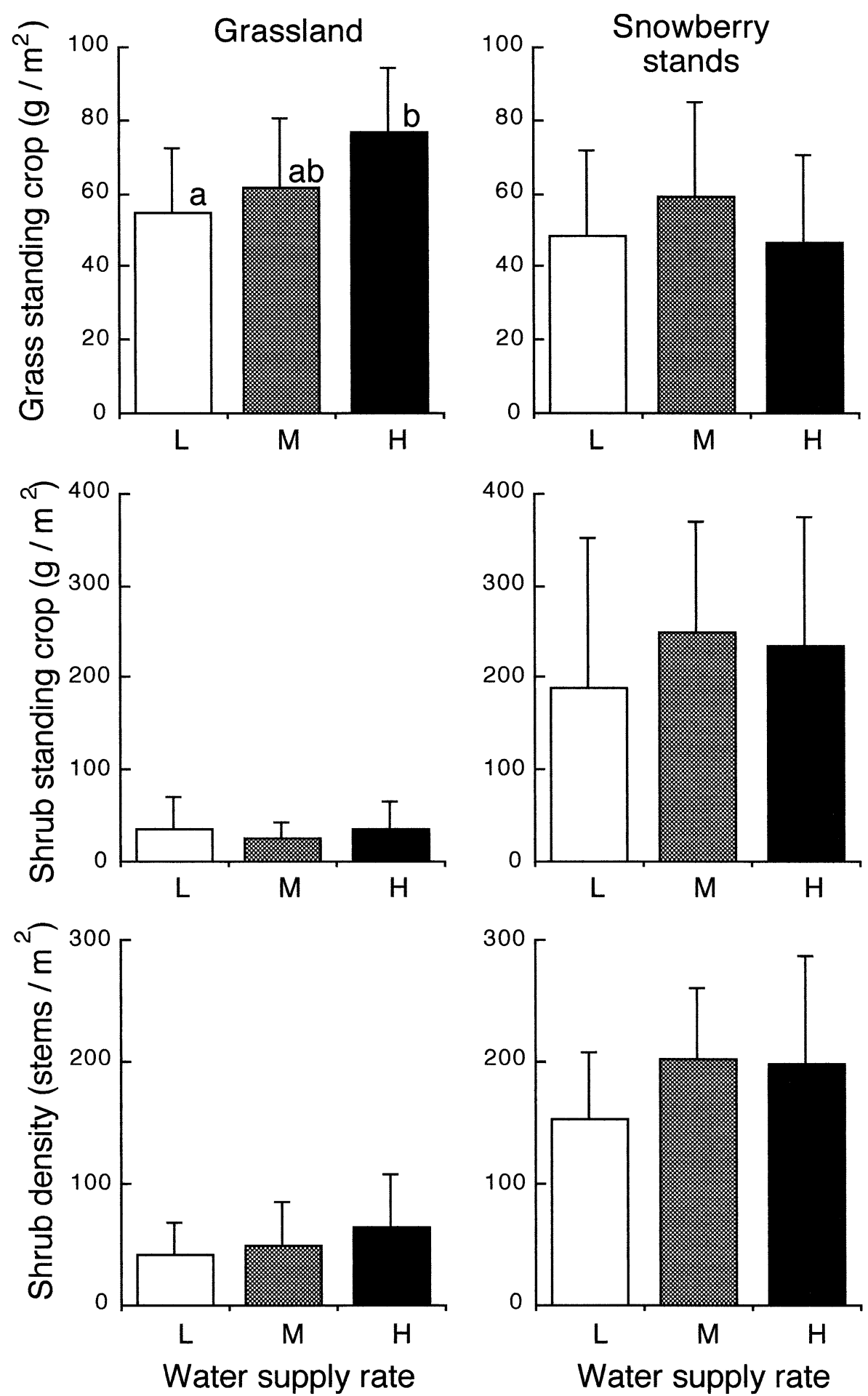

Figure 2. Mean (+ 1 S. D.) standing crop of grasses (top), standing crop of shrubs (middle) and shrub stem density (bottom) in grassland (left) and snowberry stands (right) at three rates of water supply: low (L), medium (M), and high (H). Standing crop increased significantly with water supply rate in the case of grasses only in grassland: means with common letters are not significantly different $(P>0.05)$. Shrub stem density averaged across both communities increased significantly with water supply rate. 

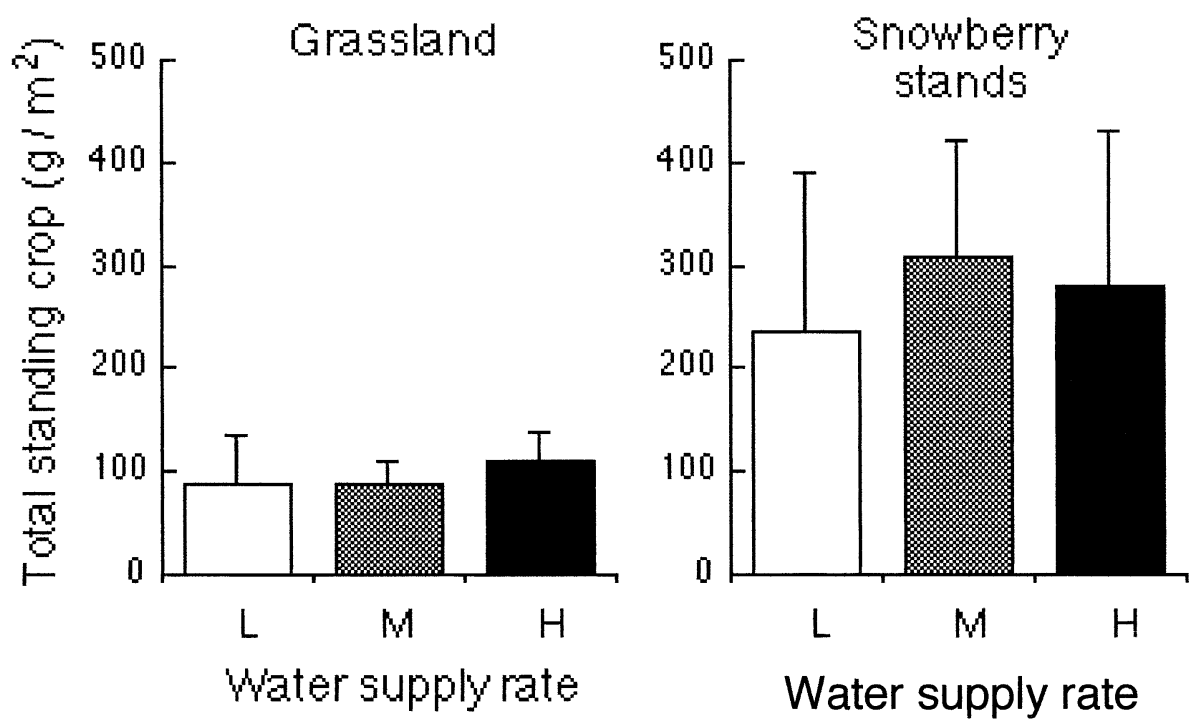

Figure 3. Mean (+ 1 S. D.) total standing crop in grassland (left) and snowberry stands (right) at three rates of water supply: low (L), medium $(\mathrm{M})$, and high $(\mathrm{H})$. Standing crop averaged across both communities increased significantly with water supply rate.

and we found no evidence that water availability influenced shrub biomass.

Grass standing crop increased with water availability only in grassland (Figure 2). The relatively weak relationship between grass mass and point intercepts $\left(r^{2}=0.61\right)$ might have obscured significant responses within shrubs, where grass mass was low. Herbaceous biomass in a Minnesota oak savanna also increased significantly with a single season of supplemental water (Davis et al. 1998). Similarly, four years of water addition to Colorado short-grass steppe more than doubled the standing crop of the dominant $\mathrm{C}_{4}$ grasses (Lauenroth et al. 1978).

The small response of grass standing crop to water availability (Figure 2) is consistent with other singleseason experiments. Water had no effect on the growth of grass transplants in simultaneous experiments nearby (Bakker and Wilson 2001; Peltzer and Wilson 2001). The effects of water availability on grassland standing crop may only appear after many years. Even in the long-term, however, the relationship between water and standing crop may be weak: a $>3$-fold among-year variation in standing crop over nearly 20 years in tall-grass prairie was only weakly correlated with precipitation $\left(r^{2}=0.37\right.$, Briggs and Knapp 1995). Similarly, water limited standing crop in only one year during an eight-year experiment in Minnesota oak savanna (Tilman 1990). Four years of water addition to Kansas tallgrass prairie had no effect on biomass (Owensby et al. 1970), and another experiment in Kansas found that added water increased productivity only in certain years (Knapp et al. 2001). In sum, there is much evidence that the link between water availability and grassland standing crop (Sala et al. 1988; Lauenroth and Sala 1992; Epstein et al. 1997) is subject to other influences.

The lack of response to water by grass biomass inside snowberry stands is consistent with the lack of response of shrub mass to variation in water supply (Figure 2), suggesting that the presence of shrubs reduced the variability of soil moisture, presumably through lower evaporation, higher interception, or higher transpiration (Fowler 1986; Vetaas 1992). Shrubs should influence water availability for grasses because their higher canopies should affect interception, and the roots of both growth forms are concentrated in the upper soil layer (Jackson 1997). Shrubs might also decrease grass responsiveness by reducing light availability (Köchy and Wilson 2000).

In contrast to the significant response by grasses to water availability, shrub mass showed no significant variation among water-supply treatments (Figure 2). This is consistent with results from Patagonia, where shrubs were found to use supplementary water in only the driest year of the three years examined, possibly because added water is insufficient to reach the deeper layer of soil where shrub roots are relatively more abundant (Golliscuo et al. 1998). The treatment effect on shrubs in both communities may have been absent 
because woody plant growth may be more strongly influenced by moisture conditions in the previous year (Bailey and Wroe 1974). Further, the relatively large standing crop of shrubs (Figure 2) may act as a reservoir of stored nutrients and carbohydrates, buffering them from short-term variation in resource availability (Fay et al. 2002).

Shrub density, averaged across both communities, was significantly lower in plots with low water availability (Figure 2). This response is consistent with the observation that woody species within grasslands are restricted to lower, wetter soils (Li and Wilson 1998). The discrepancy between the results for shrub mass and density suggests that population processes such as stem recruitment and death are not perfectly correlated with ecosystem-level variables like standing crop. The significant response of density suggests that biomass might also respond in a similar manner in the long term.

The invasion of grasslands by shrubs has been linked to increasing atmospheric $\mathrm{CO}_{2}$ concentrations, which should favor $\mathrm{C}_{3}$ shrubs (Polley et al. 1994). It has also been argued that differences caused by photosynthetic pathways are small relative to other factors, so that water-use efficiency is unimportant in explaining invasion (Archer et al. 1995). Our results support the second point of view. The lack of effect of water on shrub mass is also consistent with the suggestion that shrubs obtain their water from a different, deeper layer than grasses (Sala et al. 1989; Golliscuo et al. 1998). Similarly, water had little effect on the ability of seedlings of the shrub Prosopis to grow in the presence of herbaceous vegetation (Brown and Archer 1999).

Only relatively large rainfalls $(15-30 \mathrm{~mm})$ should penetrate canopies, litter layers and the upper layers of soil and so influence productivity (Lauenroth and Sala 1992). Our three water additions per month should have accomplished this, especially at the high level of water availability (Table 1). Thus, the weak and missing responses to water supply in our experiment cannot be attributed to insufficient water.

Leaf growth and therefore light penetration might be expected to be more sensitive to water supply than is standing crop. Light penetration, however, did not vary with water supply, presumably because leaf growth was not limited by water. Leaves, with their high nitrogen demand, might be more limited by $\mathrm{N}$ availability (Tilman 1990).
In total, our finding that water has significant effects on a subset of components of grassland vegetation is consistent with long-term, correlational studies, but we also found that a single season of altered water supply had no effect on other important aspects of the ecosystem.

\section{Acknowledgements}

We thank M. Bast, L. Ambrose, G. Köchy, and T. Willow for help in the field and in the lab, and D. Peltzer, M. Pärtel, R. Reader and referees for comments on the paper. The study was supported by a German Academic Exchange Service scholarship and a Government of Canada Award to MK and an NSERC grant to SW.

\section{References}

Archer S., Schimel D.S. and Holland D.S. 1995. Mechanism of shrubland expansion: land use, climate or $\mathrm{CO}_{2}$ ? Climatic Change 29: 90-101.

Bakker J.D. and Wilson S.D. 2001. Competitive abilities of introduced and native grasses. Plant Ecology 157: 119-127.

Barnes P. and Harrison A.T. 1982. Species, distribution and community organization in a Nebraska Sandhills mixed prairie as influenced by plant-soil-water relations. Oecologia 52: 192-202.

Bowers J.E. and Turner R.M. 2002. The influence of climatic variability on local population dynamics of Cercidium microphyllum (foothill paloverde). Oecologia 130: 105-113.

Briggs J.M. and Knapp A.K. 1995. Interannual variability in primary production in tallgrass prairie: climate, soil moisture, topographic position, and fire as determinants of aboveground biomass. American Journal of Botany 82: 1024-1030.

Brown J.R. and Archer S. 1999. Shrub invasion of grassland: recruitment is continuous and not regulated by herbaceous biomass or density. Ecology 80: 2385-2396.

Carpenter A.T. and West N.E. 1987. Indifference of mountain big sagebrush growth to supplemental water and nitrogen. Journal of Range Management 40: 448-451.

Davis M.A., Wrage K.L., and Reich P.B. 1998. Competition between tree seedlings and herbaceous vegetation: support for a theory of resource supply and demand. Journal of Ecology 86: 652-661.

Epstein H.E., Lauenroth W.K., Burke I.C. and Coffin D.P. 1997. Productivity patterns of $\mathrm{C}_{3}$ and $\mathrm{C}_{4}$ functional types in the U.S. Great Plains. Ecology 78: 722-731.

Fair J., Lauenroth W.K. and Coffin D.P. 1999. Demography of Bouteloua gracilis in a mixed prairie: analysis of genets and individuals. Journal of Ecology 87: 233-243.

Fay P.A., Carlisle J.D., Danner B.T., Lett M.S., McCarron J.K., Stewart C., Knapp A.K., Blair J.M. and Collins S.L. 2002. Altered rainfall patterns, gas exchange, and growth in grasses and forbs. International Journal of Plant Science 163: 549-557. 
Fowler N. 1986. The role of competition in plant communities in arid and semiarid regions. Annual Review of Ecology and Systematics 17: 89-110.

Golluscio R.A., Sala O.E. and Lauenroth W.K. 1998. Differential use of large summer rainfall events by shrubs and grasses: a manipulative experiment in the Patagonian steppe. Oecologia 115: $17-25$.

Harrington G.N. 1991. Effects of soil moisture on shrub seedling survival in a semi-arid grassland. Ecology 72: 1138-1149.

Hook P.B. and Lauenroth W.K. 1994. Root system response of a perennial bunchgrass to neighborhood-scale soil water heterogeneity. Functional Ecology 8: 738-745.

Jackson R.B., Mooney H.A. and Schulze E.-D. 1997. A global budget for fine root biomass, surface area, and nutrient contents. Proceedings of the National Academy of Sciences USA 94: 7362-7366.

Knapp A.K., Briggs J.M. and Koelliker J.K. 2001. Frequency and extent of water limitation to primary production in a mesic temperate grassland. Ecosystems 4: 19-28.

Knapp A.K. and Smith M.D. 2001. Variation among biomes in temporal dynamics of aboveground primary productivity. Science 291: 481-484.

Köchy M. and Wilson S.D. 2000. Competitive effects of shrubs and grasses in prairie. Oikos 91: 385-395.

Lauenroth W.K., Dodd J.L. and Sims P.L. 1978. The effects of water- and nitrogen-induced stresses on plant community structure in a semiarid grassland. Oecologia 36: 211-222.

Lauenroth W.K. and Sala O.E. 1992. Long-term forage production of North American shortgrass steppe. Ecological Applications 2: $397-403$.
Li X. and Wilson S.D. 1998. Facilitation among woody plants establishing in an old field. Ecology 79: 2694-2705.

Looman J. and Best K.K. 1987. Budd's flora of the Canadian prairie provinces. Publication 1662, Agriculture Canada, Research Branch, Hull, Canada.

Owensby C.E., Hyde R.W. and Anderson K.L. 1970. Effects of clipping and supplemental nitrogen and water on loamy upland bluestem range. Journal of Range Management 23: 341-346.

Peltzer D.A. and Wilson S.D. 2001. Variation in plant responses to neighbors at local and regional scales. American Naturalist 157: 610-625.

Polley H.W., Johnson H.B. and Mayeux H.S. 1994. Increasing $\mathrm{CO}_{2}$ : comparative responses of the $\mathrm{C}_{4}$ grass Schizachyrium and grassland invader Prosopis. Ecology 75: 976-988.

Sala O.E., Parton W.J., Joyce L.A. and Lauenroth W.K. 1988. Primary production of the central grassland region of the United States. Ecology 69: 40-45.

Sala O.E., Golluscio R.A., Lauenroth W.K. and Soriano A. 1989. Resource partitioning between shrubs and grasses in a Patagonian steppe. Oecologia 81: 501-505.

Scholes R. and Archer S. 1997. Tree-grass interactions in savannas. Annual Review of Ecology and Systematics 28: 517-544.

Tilman D. 1990. Constraints and tradeoffs: toward a predictive theory of competition and succession. Oikos 58: 3-15.

Vetaas O.R. 1992. Micro-site effects of trees and shrubs in dry savannas. Journal of Vegetation Science 3: 337-344. 